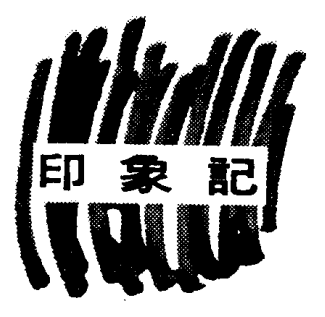

\title{
第18回日本医学会総会 および分科会から
}

第18回日本医学会総会および春の各分科会は，4月 3 日から 7 日まで東 京各地で開催された。展示部門でもテーマ展示・総合医器展が, 一般器械 ・テーマ展示を都立産業会館台東館会場, 放射線機器・ME機器・テーマ 展示を都立産業会館大手町館会場で唯され，かってないスケールと内容の 充実をみせ，大好評を博した，そこで．分科会の中から鹤科婦人科学会， 外科学会, 展示会の中からテーマ展示上総合医器展を採り上げ, その印象 記を 4 氏打愿いした。この印象記が，こんごの会のありかたに貴重な指針 となれば幸甚である。

(編集部)

第18回日本医学会総会

総 合医 器展印像記

第18回日本医学会総会総合医器展は, 4 月 3 日から 7 日まで都立産業会館大手町館と台東館 の 2 力所で極的て盛大に開催された。

大手町館では日本放射線機器工業会, 電子機 械工業会協賛により主として放射線機器, $\mathrm{ME}$ 機器の展示が行なわれた. 一方, 台東館では日 本医科器械学会協賛により一般医科器械すなお ち診断, 検查, 治療, 手術機器の展示が行なわ れた.

これに参加されたメーカー, 商社の数は 253

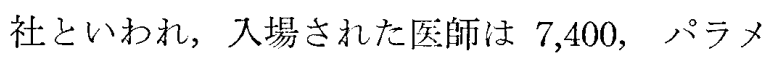
デカル 26,000といわれこれ迄化みな，12年前 東京でひらかれた医器展とほ比較にならない規
関東莪信病院 麻酔科

部 長 若杉文吉

模の大きなものであった．入場者からみた今回 の特徴住パラメデカルの方の入場が圧倒的に多 かったことしかも極めて熱心であったといらこ とで急速に進歩している医科器械を見逃さない 努力は非常に力強く感じた. 実際にこの方達の 協同なくして医学の進歩はあり得ないし，その 傾向は今後ますます強くなると考えられるから である。

さて，これらをみての印象をのべよといらこ とであるが, 総合医器展といわれるだけあって まことに膨大で，丁寧にみて迴るならたっぷり 2日を要したであるら。しかもこの開催は分科 会総会にまたがり, 特別講演, シンポジウム, 
各種催し物と重なったためなかなか十分の時間 がとれなかった．筆者も大手町館の方は全くか け歩いたし，専門外については理解できないの でその印象は甚だかたより，要を得ていないが ご容赦願いたい.

\section{放射線機器 $\cdot M E$ 機器}

大手町館の一階から上がって行って気づいた のは放射線機器がさらに能率化されたことであ る.

多くリモコン方式で, もちろんX線テレビジ ヨン装置で全体をできるだけコンパクトにして いる. しかも断層撮影, ブッキー撮影が可能で あらゆることを自動化するその度合いが急であ る.たとえばジャイロ式 X線 T V 用透視撮影台 なども新しい試みなのではなかろうか，透視台 の起倒，主回転，天板ローリングの動きを組合 せることにより多方面からの立体的観察ができ るし，撮影が可能ということはまた新たな診断 威力が増したことになる。

各機械で撮影したX線写真もたくさんかざら 机ていたがこれも素晴らしい. 国際消化器病学 会では日本の学者が出席しないと学会が成立し ないと外人がいうそうであるが，そのかげには 内視鏡はもちろんであるが，これらのX線機器 の卓越していることを見逃すことはできない.

さらに脳血管撮影をカラーで，しかもフィルム から血管像を足し算，引き算するなどの診断技 術の進歩は筆者にとって興味深かった.

$\mathrm{ME}$ 機器に関してはは多くの理論からい上い 上実用の段階に入ったという感じである.

めだったのは ICU，CCU，に使用される医用 監視装置である. まさに百花爛漫咲き乱れると いった感じであるちちっと考えただけでも約 10 社がこれと積極的にとりくんでいる．次は時 代の花形である病院におけるコンピュータの利 用である. Hospitol accounting system, Hospital information system が非常に進んできた ことである.コンピュータは出現以来大型化を 目指しており，超大型コンピュータの時分割に よる共同利用が進展してきたが医学部門では今 後はミニコンピュータがより急速に応用される ものと考えられる。
サーモグラフは前回の医学会総会では出品さ 礼なかったのではなかろらか。これは生体から 放射されるエネルギーを測定することによって 生体の温度を測定する機器である. 測定上幾つ かの問題点はあるが，生体に何ら接触すること なく測定できるということが大きな特徵であ る。 とかく生体からある情報を得るに注その接 続が問題となるができればさわらないで情報が 得たいものである.

ビデオカセット，等の応用開発も今回の特徵 である。これが普及したら医学教育の革命とも いわれる現象が起こるに違いない。

現在, 名医の手術はその病院に出向いて実際 の手術を見学するしかないが，このようなビデ オの普及からは容易にこれを学ぶことができ， それらの優れた術式が標準化し普及することが 考えられる。これは何も手術に限らず, 診断, 検査法すべてにあてはまることである.

超音波党情報獲得手段としてすなわち生体内 部における反射や透過のようすをしらべて診断 に使用する超音波診断装置も約 7 社から出品さ れ, この進歩も注目に值する.

ただ超音波洗浄装置による器具の洗浄は現に 行なわれているが術前の手洗いとすっかりこれ におきかわるであるらか。

その他心電図自動診断システムなどは回を重 祆るごとに進歩して㧍り，総体的に診断面での $\mathrm{ME}$ 機器進歩が目だっていた.

かくして大手町館は医師にとっては，この近 くに催し物が集っており，地の利を得て医師の 入場者数は台東館よりも多かった.

\section{一般医科器械}

台東館では, 理化学器械, 臨床検査器械, 診 断用器械, 麻醉・手術関係器械展示が 4 階から 7 階までを埋めつくした。

臨床生化学の面では機器分析, それも自動分 析が華やかで, 光電比色計, 炎光分析器などが 非常な進歩を示している.

機器分析でも特に筆者の注目したのは質量分 析計である、これまでの常識からすれば装置は 膨大でデリケートで，とても展示場へなど運び 込めるものではなかった，それが極めて容易に 
移動できるし，コンパクトでしかも呼気ガス， 血液ガス, 組織ガスの $\mathrm{O}_{2} \mathrm{~N}_{2} \mathrm{CO}_{2}$ について連 続分析が可能というのである. Mass range が 10 60 という制約はあるが，このような装置が 開発されたことはまことに心強いことである。

手術室関係の機器についてみると手術台では 電動による油圧駆動力の採用が多くなってい る. 以前から発表されているテーブルの着脱可 能な外国製手術台も展示されたが，まだ手術台 を含めた総合的な手術室の設計などはみられな かった. 将来の手術室注手術台も照明も麻醉器 も監視装置も全部含まれた。ことにガス管, 電 源, あら河る情報を送るコードのくみ込まれた ものが作られるに違いない。

したがって将来の手術関係器械展示には各メ 一カ一から総合的な設計の奏物展示が行なわれ ることになろう。

麻酔器にみられる傾向としては各社が安全対 策に力を注ぐようになったことである。たとえ 壮酸素の供給が減少して酸素流量が零になると 自動的に笑気流量が零になるということであ る. その他麻酔関係では使用される細かい器 具, チューブなどの材料の吟味, 使い易さに大 きな配慮がなされている，たとえば気管内チュ ーブについてみると15年も前は一重カフを鋁子 ではめこみ，これが移動して気道閉塞のもとに なったり，また空気が好けりしてこれが二重 カフとなり，そ机が今回の展示では全く一体と なったすなわちチューブにカフの固定された ものが出されている. この方が余ほど保守に便 利でかつ安全性を備えたということができる。

直接手術をする器械では整形外科関係が多か った，それも骨折の手術関係で，たとえば $\mathrm{AO}$ 骨接合用器械などは大胆な設計で着想もよい が，これをいかに上手に使いこなすかが問題で あるう。

耳鼻科の手術を坐位で行なっているとき，し ばしば気分が悪くなったり，血圧が下がったり して麻酔科医がよばれることがある，そのとき そのまま仰卧位に出来れ代処置が容易なのにと いつも感じていたが，その目的に合う，坐位か ら水平位をとることの出来る治療椅子が展示さ 机ていた。
診断器具こして注目をひくのはファイバース コープである．胃，十二指腸，大腸， S 状結腸， 気管支, 縦隔, 脳室と及ばざるはないといった ところである。精度はよくなり，ますます細い ものも可能となり将来がたのしみである，その 他ディスポの製品が多く出品されたのも今回の 特徵である。

\section{感想 と意 見}

さて，このような膨大な総合医器展を学会中 の限られた時間で能率よくみること注大抵で はない，そこでそれを可能にするにはどうした らよいか。筆者湔にも提案したことがある が，陳列されている機器がいつ考案，製作され たかを表示することである，全部に表示するこ とは困難であるから，すくなくとも今回始めて 展示するという製品に注規定の表示をする.こ 机は各商社でも当然注目してほしいし，毎回こ のような展示をみており，今回時間がなかった ら，その表示の器械だけを拾ってみることも可 能である。あるい洛社の代表的な，あるいは 最も力を注いでいる製品を幾つかに限定してそ れとわかるように表示することである. 誰しも 新しい製品, 新しい傾向をつかみたいわけで, もしこのような表示が可能であれば時間を限ら れた参観者にとっては非常に便利である.

次にこの表示と関連があるが，新製品の考 案，開発の奨励をもっと積極的にす寸めてはど らであ万うか。外国製品摸做からの脱皮はみん なで考える以外にないのである。優れた考案に 対しては当然そのアイデアを尊重し，それを認 めなけれ机ならない。この選定, 決定が非常に むつかしいが，これらの申請をそれぞれの日本 医科器械学会, $\mathrm{ME}$ 学会, 放射線学会が㛜選 し，このような学会展示は表示することであ る. 特徴は医師，機械技術者など誰でも忘募で きることで，ここで決定されたアイデァ江尊重 されアアィデアマンへの励ましとなり，この優 机たアィデアの発掘がひいては日本の医療産業 を大きくもりたてて，医学への貢献，患者への 福音につながるのである.

次に洏会場をみて感ずることは進んでいるも のはめざましく進歩しているのに対して，遅れ 
ているものは依然として放置されているいわば 凹凸が激しいということである。

今回，筆者はたまたまテーマ展示「未来の手 術室」の奏行を抢扮せつかった. 未来の手術室 を語るには過去の手術室も表現した方がよいと 考え明治・大正時代の写真を探した. 会場にか ざったのは大正 5 年の手術室で今から55年も前 である.ところがこれをよくみると現在でもそ のまま使われている器具が幾つかある，筆者は 皮肉ったわけではなかったが，現代手術室の中 のカスト，それと架台など写真と全く同じであ ることに気づいていただきたかったのである. このように60年を経ても何ら進歩していない， かえりみられないままの医科器械が随分ある.

しかも日常よく使用されている器具でも…… $\mathrm{ME}$ 機器の進歩にばかり眼をうばわれていない で，もっと身近かの問題について医師も工学者 もメ一カーも真剣に考えなければならない。

そう考えてくると今回の展示にも非常に多か った血圧計ももっと何とかならないであるう か. 同じことを何10年もやっているがもら非接 触法による血圧計などが開発されてもよいと思 う。もっとも非接触法により脈拍は計れるよう になったとニュースを耳にしている。

それと患者を移すすなわち手術台からストレ ッチャーあるいはベッドに安全確実に移すすぐ れた装置はないものであ万らか. 最近, 肥満の 患者もあってその移動にはほとほと難泚してい るが，相もかわらず大勢を集めてきて移すのは 何とも非能率的である.今回の展示ではそのよ
らなものはないかと探したが，わずかにローラ 一式の患者運搬車があるだけで，これとても恐 らく荷重を加えたらスムーズには動くまい，最 近, KIFA, Maguet 社手術台にみられるように 手術後テーブルごと患者をのせて移動させる方 法がとられているが，それでもいずれはテーブ ルから運搬車，あるいはベッドへ患者を移さな ければならない。それを安全にスムーズに行な゙ う装置の開発が期待されている.

最後に今後の展示でみた複雑な優れた高优な 器械が，またどんどん購入されるであろうが， それらの器械が，みんな十分に活躍するかとい う懸念である. 買ったけれども種々の事情で能 率上く動かせない，その中に占くなってもっと 優れた器械がでて䓡しくなったとうことはどこ の病院にもあると思う。これを打開寸るにはそ れらの複雑な器械の操作・保守を専門に行なら 人, パラメデカルの確保である.

この人達の養成, 定員化, 身分をはっきりす ることが医科器械の発展に伴ってこれからの医 療には極めて重要である。医科器械の進歩は決 して省力化にはむすびつかない，医学の進歩は， ますます金のかかることを行政当局流もち万ん 病院経営にたずさわる人は真剣に考えなければ ならない。

とに角, 医科器械はここまで進歩したという ことで今回の総合医器展は極めて有意義であっ た. 次回も 4 年後に開催されるとすればどこま で進むかがたのしみである。

第 18 回日本医学会総会

\section{学術テーマ展示印象記}

東京医科歯科大学医用器材研究所

助教授戸川達男

今回の日本医学会総会の, $8 \supset 0$ 学術テーマ 展示汢, 病院に導入されていく「機械」の役割 りについて, 各会場の担当の演出者の解釈によ
って構成されたものと見てよかろう。これは， たんに機械やパネルを示して知識を与えるだけ でなく，見る人にもそのテーマについて考える 